\title{
BIOTRANSFORMATION OF TEXTILE DYES: A BIOREMEDIAL ASPECT OF MARINE ENVIRONMENT
}

\author{
Shertate, R.S. and Prakash Thorat \\ Department of Microbiology and Research Center, \\ Shri Shivaji Mahavidyalaya, Barshi-413 411, Dist.- Solapur, MS, India
}

Received 2012-03-19; Revised 2013-01-17; Accepted 2014-09-18

\begin{abstract}
Presence of huge amount of salts in the wastewater of textile dyeing industry is one of the major limiting factors in the development of an effective biotreatment system for the removal of dyes from textile effluents. Large number of textile industries are located on the coastal areas due to ease of transport to the various places in world and help in building nations economy, but on the contrary the effluents released from these industries are proving a great problem for the marine life. Therefore, industrial effluents containing dyes must be treated before their safe discharge into the environment. There are various physiochemical methods are conventionally used. These methods are effective but quite expensive leading to the production of solid sludge. Bacterial spp. capable of thriving under high salt conditions could be employed for the treatment of saline dye-contaminated textile wastewaters. Most of the Scientists used chemical coagulation, Flocculation and Precipitation techniques for the removal of dye colors from waste waters. But this method is not cost beneficial as it generates huge amount of Sludge and to dispose the sludge is major problem. The physical methods are also not cost effective. So only biological treatment using acclimatized microorganisms could remove $99-100 \%$ dye colour from wastewater. Hence now a day most of the workers concentrated on biotransformation of textile azo dyes by adapted organisms. The use of co substrates also slightly increased the decolorization of dye solution. Some scientists showed that the products of dye degradation are not toxic to biological system. Products formed can be determined by Gas Chromatography and Mass Spectroscopy (GC-MS) technique, Fourier Transform Infra Red (FTIR) etc.
\end{abstract}

Keywords: Biochemical Oxygen Demand (BOD), Ecological and Toxicological Association of Dyes (ETAD), Organic Pigment Manufactures (OPM)

\section{INTRODUCATION}

Environmental pollution has been recognized as one of the major problems of the modern world. The increasing demand for water and the dwindling supply has made the treatment and reuse of industrial effluents an attractive option. Textile effluents are of concern because they colour the drains and ultimately the water bodies. They also diminish the water quality. The ability of microorganisms to degrade and metabolize a wide variety of compounds has been recognized and exploited in various biotreatment processes.

Textile industries consume a considerable amount of water in their manufacturing processes. Considering both the volume and the effluent composition, the textile industry is rated as the most polluting among all industrial sectors. During the dyeing process, a substantial amount of dyes and other chemicals are lost in the wastewater. Estimates put the dye losses at between 10-15\% (Vaidya and Datye, 1982). Though

Corresponding Author: Shertate, R.S., Department of Microbiology and Research Center, Shri Shivaji Mahavidyalaya, Barshi-413 411, Dist.- Solapur, MS, India 
not generally toxic to the environment, dyes colour water bodies and may hinder light penetration thereby affecting aquatic life and limiting the utilization of water (Ajayi and Osibanjo, 1980; Goncalves et al., 2000). It has been reported that a typical textile effluent contains a dye mass concentration of $10-50 \mathrm{mg} \mathrm{L}^{-1}$ (Clarke and Anliker, 1980).

The textile industries produce effluents that contain several types of chemicals such as dispersants, leveling agents, acids, alkalis, carriers and various dyes (Cooper, 1995). The textile factories daily discharge millions of litres of untreated effluents in the forms of wastewater into public drains that eventually empty into rivers (Olayinka and Alo, 2004). This alters the $\mathrm{pH}$, increases the Biochemical Oxygen Demand (BOD) and Chemical Oxygen Demand (COD) and gives the water intense colouration (Ajayi and Osibanjo, 1980). The ecosystem is affected.

Several methods are used in the treatment of textile effluents to achieve decolorization. These include physicochemical methods such as filtration, coagulation, flocculation and precipitation. Some of these methods are effective but quite expensive (Do et al., 2002; Maier et al., 2004). Biotreatment offers a cheaper and environmentally friendly alternative for color removal in textile effluents.

Synthetic dyes are used vary widely in many industries such as paper, colored photography and textile industry. There are 10,000 types of dyestuff throughout the world and approximately $7 \times 10^{5}$ tones of these are produced every year. A remarkable amount of the dyestuffs are lost during dyeing processes. These losses are mainly disposed off into aquatic environment by textile and dyeing industries and some others means.

For color removal from wastewater, biological treatment systems have been widely used such as physical and chemical methods of flocculation, coagulation (Stephenson and Sheldon, 1996; Kariminiaae et al., 2007; Patel and Suresh, 2006; Santos et al., 2007; Nishio et al., 2006), adsorption (Mckay et al., 1987; Gupta et al., 1990), oxidation, filtration and electrochemical methods (Lin and Peng, 1996). Nowadays, the most common and standard treatments applied to textile wastewater involves biological and chemical methods (Balcioglu and Arslan, 1997; Asad et al., 2007; Pandey et al., 2007).

Dark coloured effluents are produced during dye processing which are alkaline and contain organic matters (Zee and Frank., 2002). These effluents impart colour and turbidity not only to receiving body but also to the other water resources in the surrounding areas, due to seepage soil pollution as well as ground water pollution occurs.

Industrial and municipal effluents are often discharged into saline and hyper saline depression and intertidal zones, especially in developing countries (Lefebvre, 2004). The biological treatment of industrial hyper saline wastewaters and the bioremediation of polluted hyper saline environments are not possible with conventional microorganism (Oren, 2002; Pieper and Reineke, 2000).

Conventional microorganisms are unable to operate efficiently at salinities above that of seawater and their capacity of adaptation to salinity is easily lost after exposition to low salinity conditions. High and fluctuating salinity promotes the loss of cell wall integrity, protein denaturaion and changes in osmotic pressure (Pernetti and Di Palma, 2005). Such inhibition effects due to high salinity have been reported in several conventional wastewater treatment plants (Kargi and Dincer, 1997; Woolard and Irvine, 1994). As the salt concentration increases, the microbial diversity is reduced and halotolerant and halophilic species tend to dominate (Oren, 2002). Thus, halophilic microorganisms are potential candidates for the degradation of pollutants at high salt concentration. Kushner (1981) defined halobacteria based on utilization of optimum salt concentration for their growth. In this system, marine bacteria (slight halophiles) grow best at $0.2-0.5 \mathrm{M} \mathrm{NaCl}$.

Azo dyes are released in wastewater generated both by dye producing and dye consuming industries. Biodegradation of azo dyes can occur in both aerobic and anaerobic environments. These compounds are not very susceptible to oxidative metabolisms and as a consequence of this recalcitrance in aerobic environments, these compounds preferentially end up in anaerobic sediments, aquifers and ground waters (Razo-Flores et al., 1997). Rupture of the $-\mathrm{N}=\mathrm{N}$ double bond leads to the decolorization. Guo et al. (2008a) have described the decolorization of several azo dyes under anaerobic conditions by a new member of the Halomonas genus; strain GTW, isolated from coastal sediments in Dalian Bay (China). Optimal decolorization occurred at $30^{\circ} \mathrm{C}, \mathrm{pH} 6.5-8.5$ and $\mathrm{NaCl} 10-20 \%$ with yeast extract as the carbon source.

Asad et al. (2007) reported the isolation of three new Halomonas strains from textile effluents that were able to use a wide range of azo dyes as the sole source of carbon. These strains could decolorize the azo dyes in a wide range of $\mathrm{NaCl}$ concentrations (upto $20 \%)$ and $\mathrm{pH}(5-11)$. 


\subsection{History}

The history of beautifully coloured compounds (dyes) which make our life colourful and sometimes dark with death goes back over hundreds of years. Dyes have been used since ancient times for colouring and printing fabrics. Untill middle of 19 th century, all colorants used were from natural origins, synthetic dye manufacturing started in 1856, when the English Chemist W.H. Perkin in an attempt to synthesize quinine, obtained instead of bluish substance with excellent dyeing property that later became known as Aniline Purple, Tyrin Purple and Mauveine.

There are different classes of dyes. e.g., Acid dyes, Reactive dyes, metal complex dyes, Direct dyes, Basic dyes, Mordant dyes, Disperse dyes, Pigment dyes, Vat dyes, Sulphur dyes.

The principal route by which the dyes enter the environment is through wastewater. To judge the relative share of different dye classes in the wastewater of textile processing industry, dye consumption data should be considered tighter in the degree of fixation of different classes. The largest class of dye discharged in wastewater by textile industry is Anthraquinone dyes and second largest class is Triarylmethanes.

Indeed, apart from one or two notable exceptions, all the dye types used today were discovered in the 1800's (Gordon and Gregory, 1983). The discovery of the reactive dyes in 1954 and their commercial launch in 1956 heralded a major breakthrough in dyeing of cotton; intensive research in reactive dyes followed over the next two decades and indeed is still continuing today (Gordon and Gregory, 1983).

The concept of research and development was soon followed by the others and new dyes began to appear in the market. In the beginning of 20th century, synthetic dyestuff had most completely supplanted natural dyes (Welham, 2000).

\subsection{Classification of Textile Dyes}

The release of dyes into environment is undesirable not only because of their color but also their breaks down products are toxic or mutagenic to life.

In general, a dye consist of two basic components the chromogen (electron acceptor) and the auxochrome (electron donor) which regulates solubility and dyeing. The chromogen is an aromatic body containing a color giving group called as chromophore. The chromophore causes color by altering absorption bands in the visible region.
Textile dyes are usually classified according to application.

\subsection{Acid Dyes}

The dyes are insoluble in acid the solubility being confirmed by the presence of sulphonic acid group on dyes usually in form of sodium salt. The acidic conditions are used for dyeing of wool and nylon. The three most important classes of acid dyes on basic of chemical classes are Azo, Anthraquinoid and Triphenylmethane.

\subsection{Azoic Dyes}

An azoic coloring matter is a water insoluble azo compound produced in textile fibers. Azoic dyes are used for dyeing cellulosic fibers.

\subsection{Basic Dyes}

These are amino and substituted amino compounds are soluble in acid and become insoluble when alkali is added. They are used as dye acrylics or can be used with a mordant dye for dyeing wool and cotton.

\subsection{Direct Dyes}

Direct dyes are inexpensive and having auxiliary chemicals associated with direct dyeing are sodium salt, fixing agents, metal salts. Direct dyes belong to several chemical classes like Azo, phthlocyanine and stillbene.

\subsection{Disperse Dyes}

A disperses dye is defined as a substantially water insoluble having substantively for one or more hydrophobic fibers. Dyes are used on polyester, polyamide and acrylic fibers.

\subsection{Fiber Reactive Dyes}

Reactive dyes are colored component capable of forming a covalent bond between the dye molecule and fiber. Fiber reactive dyes are mainly used for cotton and cotton blends.

\subsection{Mordant Dyes}

The term mordant dye refers to a dye, which is applied to a fiber in conjunction with metallic mordant. Mordant dyes give fast, full but generally dull shades on wool and nylon.

\subsection{Sulphur Dyes}

Sulphur dyes are used for the dyeing of cellulosic fibers in medium to deep shades of generally dull brown, black, olive, blue, green, maroon and khaki hues. 


\subsection{Vat Dyes}

These are water insoluble dyes, which contain at least two conjugated carbonyl groups that enable the dye to be converted into the corresponding water-soluble ionized leuco compound.

\subsection{Dyes and Environmental Concerns}

Textile industries use different colors (dyes) in their processing units. The textile wastewater typically contains the dyes in the range of $10-200 \mathrm{mg} \mathrm{L}^{-1}$ (O'Neil et al., 1999) and therefore usually highly coloured. These dyes in some amount liberated in natural marine water bodies, which in turn affects the marine environment very adversely. The dyes present in the effluent gets mixed the sea water due to which the aquatic life is disturbed. These dyes are toxic so the life in the marine environment is threatened, which affects the quality and quantity of the sea food produced. The release of these dyes in the environment creates an ecotoxic hazard and introduces potential danger of bioaccumulation that may eventually affect man by their magnification in food chain, in successive stages.

\subsection{Bioaccumulation}

The bioaccumulation of the dyes in fish has been investigated in the research promoted by Ecological and Toxicological Association of Dyes and Organic Pigment Manufactures (ETAD). The bioconcentration factors of dyes were determined and it was observed that the water soluble dyes were not bioaccumulated whereas the water insoluble dyes bioaccumulated (Anliker, 1979). Also these dyes being recalcitrant in nature, they are potentially toxic to humans and other life (Yoo, 2000) and if these compounds magnify in the environment and enter the food chain they may endanger sustainability of life on earth.

\subsection{Dye Removal Techniques}

Textile waste can be treated in various ways. This technique includes feasibility of physical, chemical, aerobic, anaerobic, aerobic-anaerobic, biological and combined chemical and biological treatments. During the decolorization processes, it is expected that the system will prevent the transfer the pollution from one part of environment to the other (Vandevivere et al., 1998; Hao et al., 2000; Robinson et al., 2001). Several methods are used in the treatment of textile effluents to achieve decolorization. These include physicochemical methods such as filtration, specific coagulation, use of activated carbon and chemical flocculation. Some of these methods are effective but quite expensive (Do et al., 2002; Maier et al., 2004). Biotreatment offers a cheaper and environmentally friendlier alternative for color removal in textile effluents.

Marine and fresh water, soils and air have been impacted by the dispersion of contaminants. Contamination and biodegradation of the pollutants/contaminants in extreme environments has received little attention although many contaminated ecosystems present high or low temperatures, extreme acidic or alkaline $\mathrm{pH}$, high pressures or high salinity (Margesin and Shinner, 2001).

The characteristics of waste depends on quality of water (Gardinar and Borne, 1978; Norman and Roy, 1991). Type of processing involved and chemicals used. The preliminary processing treatments like sizing, desizing, scouring and bleaching produce effluents having high TDS and high BOD.

Halophilic and halotolerant microorganisms can be the best candidates for a practical biodecolorization process as they are able to grow easily at high concentrations of salts. In recent years, several studies have been focused on halophilic and halotolerant microorganisms and their abilities for decolorization of azo dyes, e.g., Shewanella putrefaciens was determined to be capable of the complete removal of Reactive Black-5, Direct Red-81,Acid Red-88 and Disperse Orange-3 (all $100 \mathrm{mg} \mathrm{l}^{-1}$ ) within $8 \mathrm{~h}$ in presence of $40 \mathrm{~g}$ $\mathrm{L}^{-1} \mathrm{NaCl}$. Another halophilic example is Halomonas sp. $G T W$ which has shown a remarkable performance in the removal of different azo dyes within $24 \mathrm{~h}$ in the presence of $150 \mathrm{~g} \mathrm{~L}^{-1} \mathrm{NaCl}$ (Amoozegar et al., 2011).

Park and Choi (1999) studied the treatment ability of an osmotolerant yeast, Pichia guilliermondii A9, for waste brine from a Kim Chi factory using a shaker-flask scale. The growth of Pichia guilliermondii $A 9$ in waste brine was not inhibited by $\mathrm{NaCl}$ concentration upto $100 \mathrm{~g} \mathrm{~L}^{-1}$.

Marine microorganisms are of immense use in the decolorization of dye because most of the industrial effluents contain high concentrations of salts, especially chlorides and salts. Recently studies have been focused on halophilic and halotolerant microorganisms and their abilities for decolorization of azo dyes which is environmentally benign, cost competitive treatment technology (Amoozegar et al., 2010).

Guo et al. (2008a) have described the decolorization of several azo dyes under anaerobic conditions by a new 
member of the genus Halomonas. Asad et al. (2007) reported the isolation of these new Halomonas strains from textile effluents that were able to use a wide range of azo dyes as the sole source of carbon.

Guo et al. (2008b) studied the incorporation of biotreatment technology of the Bromoamine Acid (BA) wastewater and azo dye wastewaters under high-salt conditions $\left(\mathrm{NaCl}, 150 \mathrm{~g} \mathrm{~L}^{-1}\right)$ in the decolorization of azo dye wastewaters by using halotolerant bacteria grown on BA wastewater and high-salt conditions.

Also, studies have been reported that the dye decolorization by facultative and obligate marine fungi viz. Flavodon flavus, Gliocladium sp., Sordaria fimicola, Halosarpheia ratnagiriensis, Algialis grandis, Hypoxylon oceanicum, (Raghukumar, 2000; Raghukumar et al., 2004). Among bacteria, Pseudomonas fluorescens, Pseudomonas aeruginosa, Bacillus subtilis, Bacillus cereus, Proteus vulgaris, Acenetobacter sp., Zooglea sp. are dominant dye decolorizer (Sudhakar et al., 2002).

Marine fungi degrade and remineralize the lignocellulose substrates by their extracellular lignin degrading enzymes. Such fungi were isolated from decaying mangrove wood, leaves, seagrass and algae (Raghukumar et al., 1994). Marine microorganisms are of immense use in the decolorization of dye because most of the industrial effluents contain high concentrations of salts, especially chlorides and salts. Besides, marine microbial enzyme would act efficiently at neutral/alkaline $\mathrm{pH}$ and wide range of temperatures to combat the neutral/alkaline dye effluents (Chandramohan, 1997).

Therefore, it may be economical to develop alternative means of dye decolorization such as bioremediation as it is an environmentally friendly, cost effective treatment technology (Hao et al., 2000; Verma and Madamwar, 2003). Microbial decolorization and degradation is an environment friendly and cost effective means to different conventional treatment technologies (Gogate and Pandit, 2004; SalahUddin et al., 2007).

Important pollutants in textile effluents are mainly recalcitrant organics, dyes, toxicants and inhibitory compounds, surfactants, chlorinated compounds, $\mathrm{pH}$ and salts. Alternations to their chemical structures can result in the formation of new xenobiotic compounds which may be more or less toxic than the potential compounds. It has been proved that dyes have been identified as the most problematic compounds in textile effluents as they are difficult to remove due to their high water solubility and low exhaustion.
The three most common groups are azo, anthraquinone and phthalocyanine dyes (Axelson et al., 2006). Most of which are toxic and carcinogenic (Acuner and Dilek, 2004). Disposal of these dyes into the environment causes serious damage, since they may significantly affect the photosynthetic activity of hydrophytes by reducing light penetration (Aksu et al., 2007) and also they may be toxic to some aquatic organisms due to their breakdown products (Hao et al., 2000).

Dyes can be removed from wastewater by chemical and physical methods including adsorption, coagulation-flocculation, oxidation and electrochemical methods (Lin and Peng, 1994, 1996). However, both the physical and chemical methods have many shortcomimgs in application, such as high-energy costs, high-sludge production, formation of by-products (Sarioglu et al., 2007). Conversely, bioprocessing can overcome these defects because it is cost saving and environmentally friendly. Fungi (Acuner and Dilek, 2004; Asgher et al., 2008; Jadhav et al., 2007 and algae (Daneshvar et al., 2007; Mohan et al., 2002) have been used in dye decolorization. Some new bacterial strains capable of decolorizing a broad-spectrum of dyes have also been isolated and characterized (Deng et al., 2008).

The biological techniques include biosorption and biotransformation in aerobic, anaerobic, combined aerobic/anaerobic conditions by using bacteria, fungi, actinomycetes, yeasts, algae and enzymes (Heinfling et al., 1998; Rafii and Coleman, 1999; Semple et al., 1999; Nyanhongo et al., 2002; Blumel and Stolz, 2003; Shrivastava et al., 2005).

\subsection{Aerobic Biological Treatment}

Conventionally activated sludge treatment of wastewater, is often an effective and economic process for reducing organic pollutants in the wastewater. Most synthetic fibers are not readily subjected to extensive biodeterioration but some processing and finishing agents are susceptible to microbial spoilage. Microorganisms can affect all stages of textile processing and storage with fungi being one of the most important microorganisms in textile biodeterioration process (Szostak-Kotowa, 2004).

The occurrence of aerobic conversions of sulphonated azo dyes were more recently reported by Heiss et al. (1992) and Shaul et al. (1991) and sometimes even complete mineralization of a sulphonated azo dye was found used under aerobic conditions. The sulphonated azo dye was used as carbon and energy source in this case (Blumel et al., 
1998). The degradation of azo dye was also observed in aerobic biofilm rectors, but this also observed in aerobic biofilm reactors, but this also may have been a result of the presence of aerobic microniches in the biofilm (Consterton et al., 1994; Hammer and Bishop, 1992; Jiang and Bishop, 1994).

Recently successful degradation of Acid red 151 as sole source of carbon was described using aerobic sequenced biofilm reactor and mineralization experiments showed that $73 \%$ of the carbon was transformed into $\mathrm{CO}_{2}$ (Quezada et al., 2000).

Pagga and Brown (1986) conducted a study on 87commercial-dye stuff. The tests were performed in the reactor designed to stimulate the condition of an adapted activated sludge waste treatment plants.

The highest COD removal efficiency obtained (90\%) corresponded to the mixed culture of activated sludge and Halobacter halobium. Kargi and Dincer (2000) conducted a further study with Halobacter halobium. This Species was cultured along with activated sludge in the fed-batch reactor. The organic removal rate was significantly improved COD removal of $85 \%$ was obtained within $9 \mathrm{~h}$ at high salt contents (3-5\%).

In order to estimate the removal efficiency of salt tolerant microorganisms, Kargi and Uygur (1996) used different types of microbial flora, namely Zooglea ramigera and Halobacter halobium. The experiments were conducted using an aerated percolation reactor with $1 \%$ salt content.

Anaerobic consortia do generally not degrade the aromatic amines but most of the aromatic amines are readily biodegraded under aerobic conditions (Baird et al., 1977; Brown and Laboureur, 1983). Although for a long time it was thought that azo dyes remained recalcitrant under aerobic conditions, some specific aerobic bacterial cultures were found able to reduce the azo linkage via an enzymatic reaction i.e., azo reductase.

Dhavene et al. (2008) studied that the biodegradation of the Diazo Reactive Dye Navy Blue HE 2R by Exiguobacterium spp. upto $91.2 \%$ within 48 $\mathrm{h}$ in static aerobic condition. He studied the toxicity of the dye on plants viz.Triticum aestivum and Ervum lens linn which are important agricultural crops. The result was that the dye affected the germination process, the growth of plant roots and shoots. Also Kale and Thorat (2010) reported the use of acclimatized aerobic bacteria for the degradation of the dye Reactive Red M5B, which showed complete decolorization and degradation of the dye containing solution.

\subsection{Anaerobic Biodegradation}

Anaerobic reduction of azo dyes using microbial sludges can be an effective and economic treatment process for removing color from dye house effluents. Previous studies have demonstrated the ability of anaerobic bacteria to reductively cleave the azo linkages in reactive dyes (Chinwedkidvanich et al., 2000; Razo-Flores et al., 1997; Loyd, 1992; Ganesh, 1992; Brown and Hamburger, 1987; Brown and Laboureur, 1983; Chung et al., 1992).

Bromley-Challenor et al. (2000) reported the decolorization of the azo dye Reactive Red 3.1 (RR 3.1) using unadapted activated sludge incubated under anaerobic condition with $2-70 \mathrm{~g} \mathrm{~L}^{-1} \mathrm{NaCl}$. In order to biologically treat (e.g., decolorize) commercial reactive dyebaths under hypersaline conditions without dilution, the use of halophilic heterotrophic cultures that can tolerate hypersaline conditions with upto $100 \mathrm{~g} \mathrm{~L}^{-1} \mathrm{NaCl}$ is essential. However, significant decolorization was observed only in $2 \mathrm{~g} \mathrm{~L}^{-1} \mathrm{NaCl}$ containing culture under anaerobic conditions.

Some researchers have isolated halophiles from the anoxic sediments of Mono Lake (Blum et al., 2001; Litchfield and Gillevet, 2002). These organisms require salt (especially $\mathrm{NaCl}$ ) and will not grow if placed in dilute ionic solutions. In addition, other researchers have reported relatively slow and partial bacterial decolorization of phthalocyanine dyes, which is due to their chemical stability and resistance to biotransformation (Nigam et al., 1996; Malpei et al., 1998; Beydilli, 2001; Fontenot et al., 2003). Therefore, the halophilic culture achieved a high degree of dyebath decolorization and could be used for the decolorization and reuse of spent reactive anthraquinone dyebaths.

Several researchers have reported that a range of substituted sulphonated naphthalene derivatives produced by the anaerobic reduction of certain dyes under autooxidation when exposed to oxygen (Nortemann et al., 1994; Kudlich et al., 1997).

Anaerobic digester was much more sensitive to chlorides than activated sludge (Burnett, 1974). Baere et al. (1984) examined influence of high $\mathrm{NaCl}$ on methanogenic activity on Anaerobic Filter (AF) process. An anaerobic and aerobic system consisting of an aerobic contactor followed by activated sludge was tested for the biological treatment of high salinity wastewater (Belkin et al., 1993).

Feijoo et al. (1995) examined the continous exposure of high salinity in pilot scale USAB and AF 
reactors. The results show that the methanogenic activity of both anaerobic processes was reduced by $50 \%$ at sodium concentrations above $20 \mathrm{~g} \mathrm{~L}^{-1}$.

\section{CONCLUSION}

Bioremediation is the pollution control technology that uses the natural microbial species to catalyse the degradation of variety of toxic compounds. Microbes can acclimatize themselves to toxic wastes and new resistant species develop naturally, which can transform various toxic chemicals to less harmful forms. The results presented here indicated that, the different textile dyes are biodegraded in $24 \mathrm{~h}$ by marine isolates. It is also observed that use of Co substrates like $1.0 \%$ glucose, $1.0 \%$ yeast extract and $1.0 \%$ Starch increased the decolourzation and degradation of the dyes.

\section{REFERENCES}

Acuner, E. and F.B. Dilek, 2004. Treatment of tectilon yellow $2 \mathrm{G}$ by chlorella vulgaris. Process Biochem., 39: 623-631. DOI: 10.1016/S0032-9592(03)00138-9

Ajayi, S.O. and O. Osibanjo, 1980. The state of environment in Nig. Pollution. Studies of textile industries in Nig. Monogra, 1: 76-86.

Aksu, Z., N.K. Killic, Ertugrul and G. Onmez, 2007. Inhibitory effects of Chromium (VI) and remazol black B on Chromium (VI) and dyestuff removals by Trametes Versicilor. Enzyme Microbial. Technol., 40: 1167-1174. DOI: 10.1016/j.enzmictec.2006.08.024

Amoozegar, M.A., M. Hajighasemi, J. Hamedi, S. Asad and A. Ventosa, 2010. Azo dye decolorization by halophilic and halotolerant microorganisms. World J. Microbiol. Biotechnol., 11: 85-94. DOI 10.1007/s13213-010-0144-y

Amoozegar, M.A., M. Hajighasemi, J. Hamedi and S. Asad, 2011. Azo dye decolorization by halophilic and halotolerant microorganisms. Ann. Microbiol., 61: 217-230. DOI: 10.1007/s13213-010-0144-y

Anliker, R., 1979. Ecotoxicity of dyestuffs-a joint effort by industry. Ecotoxicol. Environ. Saf., 3: 59-74. DOI: 10.1016/0147-6513(79)90060-5

Asad, S., A.A. Amoozegar, A.A. Pourbabaee and M.N. Sarbolouki et al., 2007. Decolorization of textile azo dyes by newly isolated halophilic and halotolerant bacteria. Bioresource Technol., 98: 2082-2088. DOI: 10.1016/j.biortech.2006.08.020
Asgher, M., S. Kausar, H.N. Bhatti, S.A.H. Shal and M. Ali, 2008. Optimization of medium for decolorization of solar golden Yellow $\mathrm{R}$ direct textile dye by Schizophyllum Commune IBL-06. Int. Biodeleriorat, Biodegradat., 61: 189-193. DOI: 10.1016/j.ibiod.2007.07.009

Axelson, J., U. Nilson, E. Terrezas, T.A. Aliaga and U. Welander, 2006. Decolorization of textile dyes reactive red 2 and reactive blue 4 using Bjerkandera spp. strain BOL 13 in a contineous rotating biological contractor reactor. Enzyme Microbial. Technol., 39: 32-37. DOI: 10.1016/j.enzmictec.2005.09.006

Baird, R., L. Cammona and R.L. Jenhins, 1977. Behaviour of benzidine and other aromatic amines in aerobic wastewater treatment. J. WPCF.

Baere, D.L.A., M. Devocht, V.P. Assche and W. Verstraete, 1984. Influence of high $\mathrm{NaCl}$ and $\mathrm{NH} 4 \mathrm{Cl}$ salt levels on methanogenic associations. Water Res., 18: 543-548.

Balcioglu, I.A. and I. Arslan, 1997. Treatability of textile industry wastewater by photocatalytic oxidation method. Proceedings of the Gebze Institute of Technology Environmental Pollution Symposium II, (ITEPS' 97), Turkey, pp: 193-199.

Belkin, S., A. Brenner and A. Abeliovich, 1993. Biological treatment of a high salinity chemical industrial wastewater. Wat. Sci. Tech., 27: 105112.

Beydilli, T.M., 2001. Reductive bio-transformation and decolorization of reactive azo dyes. Ph.D. Thesis, Georgia Institute of Technology.

Blum, J.S., J.F. Stolz, A. Oren and R.S. Oremland, 2001. Selenihalanaerobacter Shriftii gen. nov., sp nov., a halophilic anaerobe from Dead Sea sediments that respires selenate. Arch. Microbiol., 175: 208-219. DOI: 10.1007/s002030100257

Blumel, S. and A. Stolz, 2003. Cloning and characterization of gene coding for the aerobic azoreductase from Pigmentiphaga kullae K24. Appl. Microbiol. Biotechnol., 62: 186-190. DOI: 10.1007/s00253-003-1316-5.

Blumel, S., M. Cohtzen, M. Lutz, A. Stolz and H.J. Kanckmuss, 1998. Isolation of bacterial strain with the ability to utilize the sulfonated azo dye compound 4-carboxy-4-sulfoazobenzene as the sole source of carbon and energy. Applied Envl. Microbiol., 64: 2315-2317. 
Bromley-Challenor, K.C.A., J.S. Knapp, Z. Zhang, N.C.C. Gray and Hetheridge et al., 2000. Decolorization of an azo dye by unacclimated activated sludge under anaerobic conditions. Water Res., 34: 4410-4418. DOI: 10.1016/S00431354(00)00212-8

Brown, D. and B. Hamburger, 1987. The degradation of dye-stuffs. Part III-Investigation of their ultimate degradability. Chemosphere, 16: 1539-1553. DOI: 10.1016/0045-6535(87)90094-4

Brown, D. and P. Laboureur, 1983. The aerobic biodegradability of primary aromatic amines. Chromosphere, 12: 405-414 DOI: 10.1016/00456535(83)90115-7

Burnett, W.E., 1974. The effect of salinity variations on the activated sludge process. Water and Sewage Works.

Chandramohan, D., 1997. Recent advances in marine microbiology: The Indian scenario. Mar. Biotechnol., 5: 73-81.

Chinwedkidvanich, S., M. Tuntoolvest and T. Panswad, 2000. Anaerobic decolorization of Reactive dyebath effluent by two stage UASB system with Topioca as a co-substrate. Water Res., 34: 2223-2232. DOI: 10.1016/S0043-1354(99)00403-0

Chung, K.T., E.J. Sterens and C.E. Cerniglia, 1992. Reduction of azo dyes by Intestinal Microflora Critical Reviews. Microbiol., 18: 175-190.

Clarke, E.A. and R. Anliker, 1980. Organic Dyes and Pigments. The Handbook of Environmental Chemistry, Hutzinger, O. (Ed.)., Springer Verlag, New York, ISBN-10: 3642118461, pp: 181-215.

Cooper, P., 1995. Colour in Dyehouse Effluent. 1st Edn., Society of Dyers and Colourists, Bradford, ISBN10: 0901956694, pp: 200.

Consterton, J.W., Z. Lewandowski, D. DeBeer, D. Caldwerr and D. Korwer et al., 1994. Biofilms,the customizes Microniche. J. Bactriol., 176: 2137-2142.

Daneshvar, N., A.R. Khataee, M.H. Rasoulifard and M. Pourtassan, 2007. Biodegradation of dye solution containing malachite green: Optimization of effective parameters using Taguchi method. J. Hazardous Materials, 143: 214-219. DOI: 10.1016/j.jhazmat.2006.09.016

Deng, D.Y., J. Guo, G.Q. Zeng and G.P. Sun, 2008. Decolorization of anthraquinone, triphenylmethane and azo dyes by a new isolated Bacillus cereus strain DCII. Intl. Bacteriorat. Biodegradat., 62: 263-269.
Dhavene, R.S., S.S. Shedbalkar and J.P. Jadhav, 2008. Biodegradation of diazo reactive dye navy blue HE2R (Reactive Blue 172) by an isolated Exiguobacterium spp.Rb.3. Bioprocess Eng. Biotechnol., 13: 53-60. DOI: 10.1007/s12257007-0165-y.

Do, T., J. Shen, G. Cawood and R. Jeckins, 2002. Biotreatment of Textile Effluent Using Pseudomonas Spp. Immobilized on polymer supports. In: Advances in Biotreatment for Textile Processing, I.R. Hardlin, D.E. Akin and J.S. Wilson (Eds.). University of Georgia Press.

Feijoo, G., M. Soto, R. Mendez and J.M. Lema, 1995. Sodium inhibition in the anaerobic digestion process. Antagonism and adaptation phenomena. Enzyme Microbial. Technol., 17: 180-188. DOI: 10.1016/0141-0229(94)00011-F

Fontenot, E.J., Y.H. Lee, R.D. Matthews, G.X. Zhu and S.G. Pavloststhis, 2003. Reductive decolorization of a textile reactive dyebath under methanogenic conditions. Applied Biochem. Biotechnol., 109: 207-225. DOI: $10.1385 / A B A B: 109: 1-3: 207$

Gogate, P.R. and A.B. Pandit, 2004. A review of imperative technologies for wastewater treatment II: Hybrid methods. Advan. Environ. Res., 8: 553597.

Ganesh, R., 1992. Fate of azo dyes in sludges. MSc Thesis, Polytechnic Institute and State University Virginia.

Gardinar, D.K. and B.T. Borne, 1978. Textile wastewater: Treatment and environmental effect. J. Soc. Dyers Colorists., 94: 339-348. DOI: 10.1111/j.1478-4408.1978.tb03420.x

Gordon, P.F. and P. Gregory, 1983. Organic Chemistry in Color. 1st Edn., Springer-Verlag, Berlin.

Goncalves, I.M.C., A. Gomes, R. Bras, M.I.A. Ferra and M.T.P. Amorin et al., 2000. Biological treatment of effluent containing textile dyes. JSDC, 116: 393-397.

Guo, J., J. Zhou, D. Wang, C. Tian and P. Wang et al., 2008a. A novel moderately halophilic bacterium for decorizing azo dye under high salt condition. Biodegradation, 19:15-19. DOI: 10.1159/000121323

Guo, J., J. Zhou, D. Wang, J. Yang and Z. Li, 2008b. The new incorporation bio-treatment technology of bromoamine acid and azo dyes wastewaters under high-salt conditions. Biodegradation, 19: 93-98. DOI: 10.1007/s10532-007-9118-6 
Gupta, G.S., G. Prasada and V.N. Singh, 1990. Removal of chrome dye by mixed adsorbents fly ash and coal. Water Res., 24: 45-50. DOI: 10.1016/00431354(90)90063-C

Hammer, C. and P. Bishop, 1992. Transformation of azo dye AO-7 by wastewater Biofilm. Water Sci. Technol., 26: 627-636.

Hao, O.J., H. Kim and P.C. Chiang, 2000. Decolorization of wastewater. Critical Rev. Envl. Sci. Technol., 30: 449-505.

Heinfling, A., M.J. Martinez, A.T. Martinez, M. Berbauer and U. Szewyk, 1998. Purification and characterization of peroxidases from Dye decolorizing fungus Bjerkandera adusta. FEMS Microbiol. Lett., 165: 43-50. www.msk.or.kr/jsp/downloadPDF1.jsp?fileName $=5$ 03-509.pdf

Heiss, G.S., B. Gowan and E.R. Dabs, 1992. Cloning of DNA from a Rhodococcus strain conferring the ability to decolorize sulfonated Azo dyes. FEMS Microbiol. Lett., 99: 221-226.

Jadhav, J.P., G.K. Parshetli, S.D. Kalme and S.P. Govindwar, 2007. Decolorization of azo dye methyl MTCC red by Saccharomyces cerevisiae MTCC463. Chemosphere, 68: 394-400. DOI: 10.1016/j.chemosphere.2006.12.087

Jiang, H. and P.L. Bishop, 1994. Aerobic biodegradation of azo dyes in Biofilm. Water Sci. Technol., 29: 525-530.

Kale, R.V. and P.R. Thorat, 2010. Decolorization and degradation of reactive red M5B by aerobic bacteria. J. Microbial. World, 12: 53-60.

Kariminiaae, H.R., A. Sakurai and M. Sakalkibara, 2007. Deolorization of synthetic dyes by a new manganese peroxidase producing White rot fungus. Dyes Pigments, 72: 157-162. DOI: 10.1016/j.dyepig.2005.08.010

Kargi, F. and A.R. Dincer, 1997. Biological treatment of saline wastewater by fed-batch operation. J. Chem. Tech. Biotechnol., 69:167-172. DOI: $10.1007 / \mathrm{BF} 02932342$

Kargi, F. and A.R. Dincer, 2000. Use of Halophilic bacteria in biological treatment of saline wastewater by fed-batch operation. Wat. Envoron. Res., 72: 170-174.

Kargi, F. and A. Uygur, 1996. Biological treatment of saline wastewater in an aerated percolatar unit utilizing Halophilic Bacteria. Environ. Technol., 17: 320-325.
Kudlich, M., A. Keck, J. klein and A. Stolz, 1997. Localization of the enzyme system involved in anaerobic reduction of azo dyes by Sphingomonas spp. strain BN6 and effect of artificial redox mediators on the rate of azo reduction. Applied Environ. Microbiol., 63: 3691-3694.

Kushner, D.J., 1981. The Halobacteriaceae. In The Bacteria, Woese, C.R. and R.S. Wolse (Eds.), Academic Press, London, pp: 171-241.

Lefebvre, O., 2004. Application des microorganisms halophiles au treatment des effluents industrial hypersaline. Ph.D Thesis. Ecole Nationale Superieure Agronomique de Montepellier.

Lin, S.H. and F.C. Peng, 1996. Continous treatment of textile wastewater by combined coagulayoion, elecrtrochemical oxidation and activated sludge. Water Res., 30: 587-592. DOI: 10.1016/00431354(95)00210-3

Lin, S.H. and F.C. Peng, 1994. Treatment of textile wastewater by electrochemical method. Water Res., 28: 277-282. DOI: 10.1016/0043-1354(94)90264-X

Litchfield, C.D. and P.M. Gillevet, 2002. Microbial diversity and complexity in hypersaline environments: A preliminary assessment. J. Industrial Microbiol. Biotechnol., 28: 48-55.

Loyd, C.K., 1992. Anaerobic and aerobic degradation of azo dye wastewater. MSc Thesis, Virginia. Polytechnic Institute and State University.

Maier, J., A. Kandelbauer, A. Erlacher, A. Cavaco-Paulo and G.M. Gubits, 2004. A new alkali-thermostable azoreductase from Bacillus spp. Strain SF. Applied Environ. Microbial., 70: 873-844. DOI: 10.1128/ AEM.70.2.837-844.2004

Malpei, F., V. Andreoni, D. Daffonchio and A. Rozzi, 1998. Anaerobic digestion of print pastes. A preliminary screening of inhibition by dyes and biodegradability of thickeners. Bioresource Technol., 63: 49-56. DOI: 10.1016/S09608524(97)00109-0

Margesin, R. and R. Shinner, 2001. Potential of halotolerant and halophilic microorganisms for biotechnology. Extremophils, 5: 75-83.

Mckay, G., G. Ramprasad and P. Mowli, 1987. Desorption and regeneration of dye colors from lowcost materials. Water Res., 21: 375-377. DOI: 10.1016/0043-1354(87)90218-1

Mohan, S.V., N.C. Rao, K.K. Prasad and J. Kartikeyan, 2002. Treatment of simulate reative yellow 22 (Azo) dye effluents using Spirogyra spp. Waste Managem., 22: $575-582$. 
Nigam, P., I.M. Banat, D. Singh and R. Marchant, 1996. Microbial process for the decolorization of textile effluent containing azo, diazo and reactive dyes. Process Biochem., 31: 435-442. DOI: 10.1016/00329592(95)00085-2

Nishio, J.M., H.T.Z. Tokumura and Y. Kawase, 2006. Photocatalytic decolorization of azo-dye with zinc oxide powder in an external UV light irradiation slurry photoreactor. J. Hazardous Materials., 138: 106-115. DOI: 10.1016/j.jhazmat.2006.05.039

Norman, P.I. and S. Roy, 1991. Pollution control in textile industry the chemical auxillary manufacture role. J. Soc. Dyers colorists., 107: 215-218. DOI: $10.1111 /$ j.1478-4408.1991.tb01339.x

Nortemann, B., A.E. Kuhm, H.J. Knackmuss and A. Stolz, 1994. Conversion of substituted naphthalenesulfonates by Pseudomonas spp. BN6. Archives Microbiol., 161: 320-327.

Nyanhongo, G.S., J. Gomes, G.M. Gubitz, R. Zvayya and J.S. Read et al., 2002. Production of Laccase by newly isolated strain of Trametes modesta. Biores. Technol., 84: 259-263. DOI: 10.1016/S09608524(02)00044-5

Olayinka, K.O. and B.I. Aio, 2004. Studies on industrial pollution in nig. The effect of Textile effluent on the quality of ground waters in some parts Lagos. Nig. J. Health. Biomed. Sci. www.sist-sciencesdev.net/

O’Neil, C., F.R. Hawkes, D.L. Hawkes, N.D. Lourencon and Pinhero et al., 1999. Coloring textile effluentssources, measurement, discharge consenes and simulation; a review. J. Chem. Technol. Biotechnol., 74: 1009-1018.

Oren, A., 2002. Diversity of halophilic microorganisms: Environments, phylogeny, physiology and applications. J. Ind. Microbiol. Biotechnol., 28: 5663. DOI: $10.1038 / \mathrm{sj} / \mathrm{jim} / 7000176$

Pagga, U. and D. Brown, 1986. The decolorization studies of dye stuff part II. Behaviour of dye stuff in aerobic biodegradation Tests. Chemosphere, 15: 479-491. DOI: 10.1016/0045-6535(86)90542-4

Pandey, A., P. Singh and L. Ivengar, 2007. Bacterial decolorization and degradation of azo dyes. Int. Biodeteriorat. Biodegradat., 59: 73-84. DOI: 10.1016/j.ibiod.2006.08.006

Park, Y.H. and M.H. Choi, 1999. Growth of Pichia guilliermondii A9, an osmotolerant yeast, in waste brine generated from Kim Chi production. Bioresource Technol., 70: 231-236. DOI: 10.1016/S0960-8524(99)00049-8
Patel, R. and S. Suresh, 2006. Decolorization of azo dyes using magnesium-palladium system. J. Hazardous Materials, 137: 1729-1741. DOI: 10.1016/j.jhazmat.2006.05.019

Pernetti, M. and D. Palma, 2005. Experimental evaluation of inhibition effects of saline wastewater on activated sludge. Environ. Technol., 26: 695-704. DOI: 10.1080/09593330.2001.9619509

Pieper, D. and W. ReineKe, 2000. Engineering bacteria for bioremediation. Curropin Biotechnol., 11: 262-270. $\quad$ DOI: $\quad 10.1016 /$ S09581669(00)00094-X

Quezada, K., I. Linarers and G. Bultron, 2000. Use of sequencing batch biofilters for degradation of azo dyes (Acids and Bases). Water Sci. Technol., 42: 329-336.

Rafii, F. and T. Coleman, 1999. Cloning and expression in Escherichia coli of an Azoreductase gene from Clostridium perfringens and comparison with azoreductase gene from other bacteria. J. Basic. Microbiol., 39: 29-35. DOI: 10.1002/(SICI)1521-4028(199903)39:1<29:

Raghukumar, C., S. Raghukumar, D. Channaraj, T. Chandramohan and T. D'Souza et al., 1994. Laccase and other lignocellulosic modifying enzymes of marine fungi isolated from the coast of India. Bot. Mar., 37: 515-523.

Raghukumar, C., 2000. Fungi from marine habitats: application in bioremediation. Mycol. Res., 104: 385-389. DOI: 10.1017/S095375620000294X

Raghukumar, C., C. Mohandass, S. Kamat and M.S. Shailaja, 2004. Simultaneous detoxification and decolorization of molasses spent wash by the immobilized white-rot fungus Flavodon flavus isolated from a marine habitat. Enzyme Microbial. Technol., 35: 197-202. DOI: 10.1016/j.enzmictec.2004.04.010

Razo-Flores, E., B. Donlon, G. Lettinga and J.A. Field, 1997. Biotransformation and biodegradation of $\mathrm{N}$-substituted aromatics in methanogenic granular sludge. FEMS Microbiol. Rev., 20: 525-538. DOI: $10.1111 /$ j.15746976.1997.tb00335.x

Robinson, T., G. McMullan, R. Marchant and P. Nigam, 2001. Remediation of dyes in textile effluent: A critical review on current treatment technologies with proposed alternative. Biores. Technol., 77:247-255. DOI: 10.1016/S09608524(00)00080-8 
SalahUddin, M., J. Zhou, Q.J. Yuanyuan and G. Ping, 2007. Biodecolorization of azo dye acid red B under high salinity condition. Bull. Environ. Contamin. Toxicol., 79: 440-444. DOI: 10.3923/rjet.2011.97.107

Santos, A.B., F.J. Cervantes and J.B. Van Lier, 2007. Review paper on current technologies for decolorization of textile wastewaters: Perspectives for anaerobic biotechnology. Biores. Technol., 98: 2369-2385. DOI: 10.1016/j.biortech.2006.11.013

Sarioglu, M., U. Ball and T. Bisgin, 2007. The removal of C.I.Basic Red 46 in mixed methanogenic anaerobic culture. Dyes Pigmets, 74: 223-229. DOI: 10.1016/j.dyepig.2006.02.001

Semple, K.T., R.B. Cain and S. Schmidt, 1999. Biodegradation of aromatic compounds of Microalgae. FEMS Microbial. Lett., 170: 291300. DOI: 10.1111/j.1574-6968.1999.tb13386.x

Shaul, G.M., T.J. Holdsworth, C.R. Demmpsey and K.A. Dostal, 1991. Fate of water soluble azo dye in activated sludge process. Chemosphere, 22: 107-119. DOI: 10.1016/0045-6535(91)90269-J.

Shrivastava, R., V. Christian and B.R.M. Vyas, 2005. Enzymatic decolorization of sulfonphthalien Dyes. Enz. Microbiol. Technol., 36: 333-337. DOI: 10.1016/j.enzmictec.2004.09.004.

Stephenson, R.J. and J.B.D. Sheldon, 1996. Coagulation and precipitation of a mechanical pulping effluent by: I.Removal of carbon color and turbidity. Water Res., 30: 781-792. DOI: 10.1016/0043-1354(95)00213-8.

Sudhakar, P., R. Palaniappan and R. Gowtisankar, 2002. Degradation of azo dye (Black-E) by an indigenous bacterium Pseudomonas sp. BSP-4. Asian J. Microbiol. Biotech. Env. Sc., 4: 203-208.
Szostak-Kotowa, J., 2004. Biodeterioration of textiles. Intl. Biodeteriorat. Biodegradat., 53: 165-170. DOI: 10.1016/S0964-8305(03)00090-8.

Vaidya, A.A. and K.V. Datye, 1982. Environmental pollution during chemical processing of synthetic fibers. Colourage, 14: 3-10.

Vandevivere, P.C., R. Bianchi and W. Verstraete, 1998. Treatment and reuse of wastewater from the textile Wet Processing industry: A review of emerging technologies. J. Chem. Technol. Biotechnol., 72: 289-302. DOI: 10.1080/10978526.2011.609078.

Verma, P.R. and D. Madamwar, 2003. Decolorization of synthetic dyes by a newly isolated strain of Serratia marcescens. World J. Microbiol. Biotechnol., 19: 615-618. DOI: $10.1023 / \mathrm{A}: 1025115801331$

Welham, A., 2000. Theory of dyeing (secret of life). J. Soc. Dyers Colour., 116: 140-143. DOI: 10.1016/j.desal.2008.05.005vs.

Woolard, C.R. and R.L. Irvine, 1994. Biological treatment of hypersaline wastewater by a biofilm of halophilic bacteria. Water Environ. Res., 66: 2350-2355. DOI: 10.1186/1475-2859-7-15v.

Yoo, E.S., 2000. Biological and Chemical mechanisms of Reductive decolorization of Azo Dyes. A Ph.D.Thesis, submitted to Berln University, Berlin.

Zee, V.D. and P. Frank, 2002. Anaerobic Azo dye Reduction. Ph.D. Thesis submitted to Wageningen University, Wageningen, Netherlands. 